\title{
EMPLOYEE PERCEPTION AND PERFORMANCE APPRAISAL : AN EVALUATION OF SELECTED DEPOSIT MONEY BANKS IN PORT HARCOURT
}

\author{
Bienwi-Patrick, Ledum \\ Department of Management, University of Port Harcourt Business School
}

B. Chima Onuoha

Department of Management, University of Port Harcourt.

\author{
Best C. Eke \\ Department of Management, University of Port Harcourt
}

Article DOI: $\underline{\text { https://doi.org/10.36713/epra5285 }}$

\begin{abstract}
Performance Appraisal system represents a major tool for most of the organizations to evaluate various aspects of their employees. Despite the prominence of the organizational phenomenon, very limited research is done in Nigerian organization in this area.To analyses the perception of employees regarding the performance appraisal system implementation, the Deposit Money Banks in Port Harcourt, Rivers state are selected due to the reported high rate of staff turnover. In order to analyze the perception of employees regarding the new system and its implementation, 33 item questionnaires consist of 4 independent and one dependent variables was distributed among 150 employees who were acquainted with the Performance appraisal procedure. The study employed four measures of performance appraisal which are Procedural justice, Goal setting, feedback and Pay for performance and one criterion variable, the employee perception towards these performance appraisal process. The instrument used was a 5 point Likert scale questionnaire. Factor analysis and regression analysis was done through the Statistical Package for Social Sciences version 25.The result shows the process was implemented as per organization guidelines to the overall satisfaction of employees. There are however some areas of improvement which have been noted in the conclusion. The results and outcome are in line with international published data.
\end{abstract}

KEYWORDS: Employee Perception, Performance Appraisal, Procedural Justice.

\section{INTRODUCTION}

Performance appraisal is an integral part of human resource management activities; it is born out of a growing concern to all members of organizations including managers, employees and even customers. It consists of series of continuous process, which include performance planning, performance coaching, performance appraisal and rewarding performance (Aarathy \& Raju, 2018). Together these processes strive to improve employee and organizational performance. Extensive published data is available from around the world focusing on various aspects of the Appraisal system. Performance management according to Armstrong (2006) is a system which focuses on individual progress towards the achievement of his set goals, and targets the system also focuses on the career development and individual improvement in performance standards (Armstrong, 2006). It is created to set measurable standards for individuals of the organization on a set format designed by Human 
resource department with the consent and approval of senior management.

The misconception in the past about performance appraisal system was simply filling out forms designed by the organization Human Resource team and writing a review by ticking the boxes given in the form (Curzi, Fabbri, Scapolan, \& Boscolo, 2019). This misconception about the system that it is only to fill the forms has drastically changed overtime. The system as opposed to previous misconception is a flexible continuous process and not a system which is rigid only for once a year implementation (Armstrong, 2006).

The Performance appraisal system was first introduced in Nigeria by Multinational companies. Since the MNCs have a uniform system worldwide, it was easy for them to replicate the same with little modification in Nigeria. Literature on performance appraisal suggests that that appraisal procedure as a whole has significant effect on employee perception towards performance appraisal (Judge \& Ferris, 1993). This relationship has also been revalidated in several other studies (Bowen \& Ostroff, 2004, Waheed et al., 2018). Additionally, earlier studies also show that different component of appraisal procedure also affects employees perception. For example in one study it was found that the fairness of appraisal performance positively effects employee's perception of performance appraisal system (Bowen \& Ostroff, 2004). Researchers in their studies have also found that the fairness in the appraisal system as a whole would lead to positive effect on employee perception towards appraisal system (Cropanzano, 2001).Cleveland and Murphy (1989) in their research article based on 243 responded interview has also confirmed that performance appraisal has greatest impact on salary administration and performance feedback. Other studies have also validated that procedural fairness and monetary benefits are significant predictors of job satisfaction and employees performance appraisal performance (Curzi et al., 2019; .Tyler et.al, 1985, Tyler, Rasinski, \& McGraw 1985).

But despite the introduction of performance appraisal to Nigerian organization and banks as a whole, various renewed research on its efficacy and its internal perception are still lacking. Many studies have explored the relationship between employee perception and procedural justice, Employees perception and goal setting, feedback and performance based pay in various countries and regions but few studies have measured this relationship in the context of Nigerian market. Limited research has been carried out on this issue which lacks theoretical grounding and integration of resemblance in a systemized manner. This is the first study which is being carried out in the domain of the financial industry which transform their employee evaluation from ACR to Performance appraisal. It therefore becomes imperative to undertake a review of employee perception on performance appraisal using a fundamental industry such as the Deposit Money Bank as a point of study.

\section{Problem Statement}

Many Nigerian firms, especially the financial institutions have moved from ACR (annual confidential report) where there was no involvement of employees in the process to performance appraisal system which is a participative process. To know the employees response about the new system when the questions was asked from the organization senior management, are the employee satisfied, there was no absolute answer which could prove their satisfaction. In many organizations the performance appraisal is taken as a routine exercise due to which most employees perceive this process only a routine exercise which is done once a year and it has no implication on their career. The perception about the forms which are filled during performance appraisal exercise is that the forms will be kept in files and will only be used for next year (Waheed et al., 2018). Previous research (Banks \& Murphy, 1985; Milkovich \& Read, 1992) observed that the most important challenge faced by the organization is employee perception about the process fairness. Canet-Giner et al., (2019) also observed the same and says that if the process of performance appraisal is not fair this can become a source of extreme dissatisfaction. When the shift from ACR to performance appraisal system in the target organization was implemented, the process has involved both raters and rates to greater extinct. A major exercise was done preparing all the guidelines and agreeing on various forms and competencies.

Based on the aforementioned, it therefore becomes imperative for employee perception on the performance appraisal process be evaluated to enable awareness of how the staff perceives the performance appraisal system. Despite various literature existent in this area, the study is yet to observe one carried out in the Nigerian banking sector, therefore, this makes this study imperative.

The study seeks to evaluate the influence of employee perception on performance $=$ appraisal, to undertake this accurately, the study specifically seeks to;

i. Examine the effect of procedural justice on employees perception towards performance appraisal

ii. Ascertain the effect of goal setting on employees perception towards performance appraisal.

iii. Evaluate the effect of feedback process on employees perception towards performance appraisal. 
iv. Determine the perception of employees about the pay for performance.

From the theoretical perspectives, this study of performance appraisal would help to find out about the employees perception in a public limited company in a Nigerian market. This survey is an extension of knowledge of performance appraisal system based on published research data in international market. From the perspectives of readers which include management and HR specialist, this study would help to understand the Nigeria's employee's views towards performance appraisal. By having a better understanding of the performance appraisal process and opinion of the employees about implementation process the organizations can make better decisions regarding PAS implementation process.

Actions such as how to improve the Procedural justice, what is the significance and importance of involving the employees in goal setting process and what impact feedback will have on their performance will also be discussed .It will also strengthen how important is the link of pay raise to individual performance discussed and documented in performance appraisal review. This study is segmented into five section. This section introduces, while the second section reviews various conceptual, empirical and theoretical literature. Section three outlines the study methods, while section four presents results and discusses findings and section five concludes and recommends.

\section{LITERATURE REVIEW}

\subsection{Theoretical Framework}

\subsubsection{Performance and Trust Theory}

The proponent of this theory is Cummings (1983) who suggests that organisational justice plays a mediating role in the relationship between performance management practices and organisational commitment (McAllister, 1995), and trust creates conditions that have an emotional impact on employee responses to commitment and performance appraisal practices (Farndale et al., 2011; Macky \& Boxall, 2007). Trust can be defined as "a psychological state comprising the intention to accept vulnerability based upon positive expectations of the intentions or behaviours of another" (Rousseau, Sitkin, Burt \& Camerer, 1998, p. 395). For the purpose of this research, trust is defined as the relationship between an employee and a line manager. Aryee, Budhwar and Chen (2002) explained that trust could be viewed from a macro perspective of the relationship between the employer and senior management and a micro perspective of the relationship between the employee and the line manager According to Cummings (1983), performance appraisal can have an effect on an employee's trust in the organisation. He explained that self-appraisal in a performance evaluation system is positively associated with trust (Cummings, 1983). Trust can be enhanced through feedback of appraisal results to the appraisee. Mayer and Davis (1999) explained that should the performance appraisal system reflect the employees' true performance, employees' trust in the performance appraisal is enhanced. Employees' link to true performance, with rewards and recognition based on the performance appraisal, forms the basis of their trust in the performance appraisal system. In conclusion, they denoted that trust is affected by an appraisal system that increases the perceived linkages between performance and rewards, which affect the trust relationship (Mayer \& Davis, 1999). Farndale et al., (2011) established that there is a link between employee behaviour, their attitudes (such as trust in the organisation and perceptions of justice and commitment) and their experiences of performance appraisal practices. Aryee et al., (2002) state that trust in the organisation partly mediates the relationship between procedural and distributive justice and the employee's attitudes of organisational commitment, turnover intentions and job satisfaction.

\subsubsection{Process Based Theory of Human Resource Management}

The process based theory which was founded by the study of Bowen and Ostroff (2004) suggest interpreting Human Resource Management (HRM) practices as messages that organizations send to their leaders and employees to inform about which results and behavior (e.g., IWB) are expected, supported, encouraged and eventually rewarded (Chang, 2005; Bednall et al., 2014; Bos-Nehles and Veenendaal, 2017; Escribá-Carda et al., 2017; Sanders et al., 2018). In accordance to this signaling perspective, HRM practices are able to elicit the desired behavior and attitudes particularly when employees perceive HRM practices as understandable (i.e., they are not ambiguous), consistent (they indeed do what they are intended to do, e.g., they promote IWB), and consensual (employees agree about the perception of those HRM practices).

Consistently, the basic function of performance appraisal is identifying and communicating individual responsibilities, expected objectives, required behavior and competences, ensuring the alignment between individuals' behavior and goals and the organization's strategic goals (DeNisi and Sonesh, 2011; DeNisi and Murphy, 2017). Thus, performance appraisal may stand out in the realm of HRM practices that organizations aimed at coping with the strategic challenges of digitalization may use in support of leaders to encourage employees' innovative work behavior (IWB). More specifically, a first characteristic of performance appraisal which may have a potential signaling effect in terms of promotion of IWB, is the 
formality of the appraisal system, i.e., the extent to which leaders give employees feedback by means of formal tools and procedures, at prescribed times (e.g., traditional annual or bi-annual appraisal reviews conducted through a standard rating form). This characteristic is widely discussed in the lively debate on performance appraisal, where critics question this feature and point to the increasing number of leading corporations that are substituting their traditional formal performance appraisal system with informal feedback basically because they deem the former inappropriate to help leaders to support employees in learning new things and being creative and innovative (Pulakos and O'Leary, 2011; Pulakos et al., 2015; Cappelli and Tavis, 2016). There are indeed some studies showing a weak positive or even a negative relationship between formal HRM practices as perceived by the employees and IWB (Bednall et al., 2014; Sanders and Yang, 2016). However, there is also evidence of a positive relationship between formal appraisal and the generation and use of new ideas at work (Shipton et al., 2005, 2006; Gorbatov and Lane, 2018). Such evidence echoes recent studies which have pointed out that structuring HRM processes is perceived as related positively to employees' creativity (Binyamin and Carmeli, 2010; Sanders et al., 2018). Moreover, it is consistent with Bowen and Ostroff's (2004) conceptualization, which suggests that formal HRM practices may increase the understandability and transparency of such practices thereby raising the likelihood that these practices will have the desired effect, i.e., in our case, promoting IWB.

\subsection{Conceptual Framework}

\subsubsection{Concept of Performance Appraisal}

Various authors have defined performance appraisal in their own words. According to Lansbury (1988)(cited in Islam \& Rasad, 2005) Performance appraisal is defined as "the process of identifying, evaluating and developing the work performance of employees in the organization, so that the organizational goals and objectives are more effectively achieved, while at the same time benefiting employees in terms of recognition, receiving feedback, catering for work and offering career guidance". According to Armstrong (2000) Performance appraisal can be defined as "the formal assessment and rating of individuals by their managers, usually, at annual review meeting". In a book 199 Pre-Written Employee Performance Appraisal" by Stephanie (2007) the process is defined "as an evaluation process which typically involves rater (mostly direct manager) and his employee on a regular basis which is on annual basis or more than once in specified period".

\subsubsection{Employees Perception of Performance Appraisal}

Mohrman et al (1989) in their book, 'Designing Performance Appraisal System' have mentioned that performance appraisal system has a number of positive and negative outcomes. The positive outcomes include the improvement in employee motivation which may result in improved productivity and increased selfesteem. The person will be able to get a clear role understanding.

This process will help to develop a fair process of salary administration and distribution if performed properly. At the same time it is important to note that if the performance appraisal is not done and implemented properly it can create negative outcomes such as employee demotivation, and waste of time and money on forms and other related support activities. (Murphy \& Cleveland 1995, Lawler, Mohrman, 1984 \& Bernardin \& Beatty, 1984 ;) Many researchers point out that the performance appraisal system communicate and determine the pay, allows the rate to give feedback about his performance and share his feeling and agree on mutual goal setting. Based on the above discussion it has been hypothesized that:

\subsubsection{Procedural Justice and perception toward employees performance}

According to Greenberg (1990), Procedural justice is the fairness of the performance appraisal process used to arrive at the outcome-distribution. The employees associate the Procedural justice with the fairness of the process and its outcome .It also increase the fairness of the process. While doing performance appraisal many researchers has observed that procedural justice and job satisfaction and feedback are highly interrelated which leads to greater job satisfaction (Fletcher \& MCdowall, 2004: Sabeen \& Mehboob, 2008).

Murphy (1978) and Cleveland (1980) showed in their research that if the Performance appraisal systems meet certain conditions the employees will accept it to be fair. Among these conditions includes frequency of feedback, the opportunity for employees to express their feelings during the review process, goal setting and knowledge of the supervisor about the appraisal process. Greenberg (1990) also suggest and proposed five categories which increased the fairness of the process .These categories are (1) Supervisor gets feedback of the employees prior to the formal appraisal process and use it in the appraisal.(2) Make it a two way communication process between the appraise and appraisal.(3) the ability of the rate to challenge the rating data(4) supervisor is consistent in rating process and (5) Raters knowledge about the rating process. Another researcher (folger, et all 1992 ) in a three stage ,model for fair Performance appraisal review has commented that the employee has to receive advance 
notice on performance appraisal standards ,timely and frequent feedback on observations of employees work and employees are encouraged to challenge the process if he thinks the process is unfair.

Judge \& Ferris (1993) observed that reward and promotion besides other HRM factors are important factors during performance appraisal to influence employee perception. Bowen \& Ostroff (2004) discussed that HRM decision makers agreed on two factors which are important for developing employee perception. These factors are the system fairness and procedural justice. Cropanzano (2001) also observed that procedural justice in organization put a positive impact on employee perception (Cropanzano, 2001).

\subsubsection{Goal Setting and Performance appraisal}

Goal setting is the process when the goals are set for the evaluation and measurement of individual performance for a given period. According to Longenecker (1997) formal appraisal process have been found to be potentially effective for Goal setting and performance planning. According to Cameron (1980) some organizations where either the goals are not properly defined or are even contradictory to each other. There is greater satisfaction associated with performance appraisal when Goal setting is linked and associated with performance appraisal process. (Dobbins et al., 1990). Stevens (1990) also emphasized that each employee to assigned specific goals which he has to pursue and achieve during the appraisal period which is a year. During the annual performance review rating of employee should be linked with the achievement of these goals.

Deborah(1997) in her paper "Designing Effective Performance Appraisal System "mentions that it is a big challenge to develop an appraisal system which is representative of the employee performance. Managers when conducting the appraisal session should document their observations regarding the employee performance in writing and should also ask the subordinate to come prepared with his written observations and self-appraisal.

Another aspect to evaluate employee perception is goal setting. The literature review shows that goal setting and its proper evaluation has influenced employee perception. Three different studies has observed and suggest that goal setting and feedback are interrelated .In order to change the employee behavior and performance in a positive way goal setting and feedback combination is the appropriate combination (Locke \&Bryan (1969), Erez (1977) and (Latham et al., (1978).Various studies have confirmed practical utility of goal setting as a method changing of behavior and performance (Latham \& blades, (1975) Latham \& kinne,(1974). A study on utilizing feedback and goal setting has demonstrated that feedback and goal setting can be used to improve the performance appraisal skills (Waheed et al., 2018). During Literature search Majority of the goal setting discussion is not related to appraisal however the above studies are related to the appraisal evaluation and the Longenecker has also mentioned in his study the relationship of goal setting with the appraisal and further emphasized that if the goal setting is effective that leads to greater employee satisfaction. (Longenecker, et al., 1994 cited in GRobert 2003) article).

\subsubsection{The role of feedback in performance Appraisal}

Feedback is the process when rater during the performance review evaluation process examines the work of the rate and gives him or her verbal and written feedback on his/her performance. Many research scholars has emphasized on feedback and its importance during performance appraisal. Delpo (2007) in his book, The Performance Appraisal Handbook has mentioned that feedback during performance appraisal as per the situation and performance can be positive or negative. This is an important part of the performance evaluation system. Therefore in result of feedback, employee will be able to know what he can do further to achieve his goals. Most systems are developed in response to employees needs to evaluate their performance. It is through the performance appraisal exercise that the employee gain information about their efforts and achievements. The feedback is about providing information to the employee regarding what he has done in the previous year under review. In most cases feedback is incorporated in the appraisal form and some information is given in the form which facilitates the employee to understand how he is perfuming in the eyes of the company. Although all measurement data provides in the form has some builtin feedback, but few of the employees can adjust their performance based on the data provided. (Moravec 1996, Longenecker 1997)

On the positive side, a majority of appraisers appear to do reasonably well in terms of providing feedback on staff performance, taking the appraisal seriously and being as objective as possible. In majority of cases, appraises are involved in setting their performance goals and there appears to be agreement between appraiser and appraise on what constitutes "good" performance. However at the same time it is not generally the case that a majority of respondents do not agree that their appraisers provide them with regular informal feedback on their progress towards objectives and agrees that appraisers take their staffs' careers aspirations seriously.

Robert (2003) also has emphasized on the feedback process and mentioned that in order to make the performance appraisal process effective the feedback process should be both formal and informal 
(Roberts 2003). Feedback on performance is another important area where the employee perception can be influenced with regular and timely feedback on his performance .This topic is widely discussed in detail in various studies Erdogan (2002) mentioned feedback is a major factor which effect employee perception. He further mentioned about the procedure while giving feedback. Erdogan viewed feedback as integral part of the PA process and is also an important component of PA process. Employee perception about performance appraisal system will be positive if they know that the appraisal process is useful tool to get feedback which enables them to improve their performance (Mullins, 2007). Cleveland and Murphy (1989) in their article based on 243 responded interview has confirmed that performance appraisal has greatest impact on salary administration and performance feedback.

\subsubsection{Pay for Performance and Perception on Performance Appraisal}

According to business dictionary a performance based pay is monetary benefit or reward for employees linked to their performance. (http://www.businessdictionary.com) Compensation given on the basis of an employee acquiring a critical skill or knowledge. Roberts, 2001) also discussed the use of performance appraisal for setting up monitory reward.

Milkovich and Wigdor (1991) argued that there is evidence that pay-for-performance systems can have beneficial effects for the organization. Cleveland et al., 1989 in his research article" multiple use of performance appraisal prevalence and correlates" has mentioned that $63 \%$ of the respondents agreed that the Performance appraisal is used for salary administration. (Guinn and Corona, 1991) as cited in Boice and Kleiner article "Designing effective performance appraisal systems "Observed that when pay is not linked directly to the performance appraisal process the employees will not take the appraisal process seriously. (Boice and Kleiner,1997).

Griffin (1987) in his book state that pay should be linked to performance so that when performance shown improvement it should lead to higher pay .He further observed that the employee must have confidence and trust in the fairness of the performance evaluation which will establish the effectiveness of the merit system

Another important factor which can influence the employee perception is the pay and raise in the pay based on his performance. The pay for performance or pay rise or compensation is major factor which makes the employee perception positive or negative. Folger (1989) in his study confirmed that full regression analysis shows the procedural justice and feedback which is a component of a procedural justice is related to satisfaction with raises. Another study on performance appraisal has further emphasized that procedural fairness is a significant predictor for pay and job satisfaction (swierez et. 1999).Tyler et.al (1985) also observed in his study outcome that the Procedural justice besides feedback makes a significant contribution to pay satisfaction, (Tyler,Rasinski, \& McGraw 1985).

Performance base pay is another important and emotional factor for most of the employees. However performance base pay is only part of the reward system which also includes non-financial rewards. Many researchers has mentioned that the discussion on pay during the performance appraisal review discussion session has shown higher employee satisfaction Stephhan \& loveland,(1986). De Silva (1998) has also mentioned that performance related pay system has little impact on employee overall behavior if used in isolation. For a Performance appraisal system to be effective in relations to pay for performance the salary adjustment should follow after the performance review process is conducted, Boice \& Kleiner (1997).

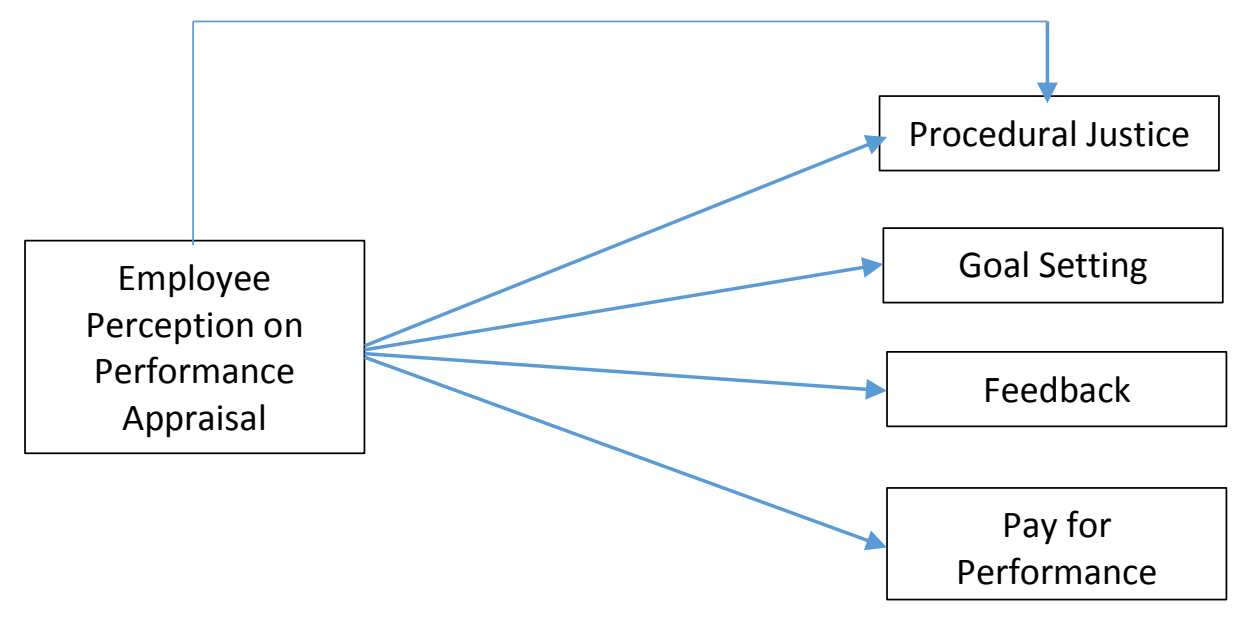


Conceptual Framework on Employee Perception on Performance Appraisal in selected Deposit Money banks in Nigeria.

\subsection{Empirical Framework}

Curzi, Fabbri, Scapolan, and Boscolo (2019) in an ettempt to evaluate employee perception on performance appraisal carried out a survey on 865 employees working in large, multinational firms operating in digitalized sectors or industries with the potential to become digitalized. The study collected data on the main characteristics of the performance appraisal systems adopted by the firm where respondents work, as perceived by employees themselves. The study gathered also data on the respondents' overall perception that performance appraisal boosts innovative work behavior (IWB). Then, the study employed logit analysis to test the relationship between data on performance appraisal systems and data on the effectiveness of performance appraisal as a booster of IWB. The results reveal that, as compared to informal feedback, formal performance appraisal is more likely to reduce the perception that performance appraisal promotes individual innovation and creativity at work. In addition, the study found that in the employees' perception performance appraisal focused on the achievement of pre-set, quantitative outcomes is more likely to affect positively IWB than appraisal focused on pre-defined skills that employees exhibited performing their work. However, performance assessment focused on the new competences developed by the employees has a perceived positive impact even stronger than resultoriented appraisal. Taken together, these results contribute to advance our understanding of how organizations should evaluate employees in the digitalization era.

Canet-Giner, Redondo-Cano, Saorín-Iborra, and Escribá-Carda (2019) analyzed the impact of employees' perception of performance appraisal (PA) practices on innovative behavior (IB). The authors also propose to analyze consistency, a dimension of Human Resource Management (HRM) system strength, as a moderating variable in the aforementioned relationship. A quantitative study was conducted in the study, using a sample of 166 employees carrying out highly qualified, intensive knowledge jobs in four industrial companies in the Valencian region of Spain. The hypotheses were tested by applying the Smart-PLS 3.2 software. The findings confirmed that in a context of professional and qualified work, PA practices have a direct and positive effect on IB. However, the results obtained did not enable us to affirm that employee perceptions of the consistency of the HR system moderated the relationship between PA and IB.

Waheed, Abbas, and Malik (2018) examined the direct and indirect relationship between perceptions of performance appraisal quality (PPAQ) and innovative behavior mediated through psychological empowerment. A total of 360 faculty members participated in the study from twelve public sector higher education institutes in Islamabad, Pakistan. Partial least squares structural equation modeling (PLSSEM) is used for statistical analysis of the quantitative data collected through self-administered questionnaire. Results demonstrated that PPAQ is positively related with innovative behavior. The findings also support the mediating role of psychological empowerment and the moderating role of perceptions of human resource management (HRM) system strength. We contribute to the literature by demonstrating that HRM content and process are two complementary facets of an HRM system in bringing out positive work behaviors. A number of practical implications and directions for future research are outlined.

Aarathy and Raju (2018) evaluated the perception of employees towards performance appraisal system. This study is conducted with the help of primary data collected from seventy five employees of IT sector using convenience sampling method. It was observed from the study that performance appraisal increases quality and quantity of work. It is very effective and useful to reduce problems, anger, stress and grievances of employees to overcome their problems.

Boachie-Mensah and Seidu (2012) focused on employees' perceptions of performance appraisal biases or errors, and examined the implications for developing and implementing an effective appraisal system in a polytechnic in Takoradi, Ghana. The study also sought to identify pragmatic ways to ameliorate any appraisal biases that may be present in the institution's appraisal system. Data was collected from 140 employees of the institution, which included both academic and administrative staff who had worked in the institution for at least two consecutive years, and whose work had been appraised previously. A content validated semistructured interview schedule was used to interview the respondents. The data collected was analysed, using descriptive statistics, in order to address the research questions. The results of the study indicate that employees of the institution perceive that the performance appraisal system of the institution is affected by subjectivity, and is influenced by some major errors.

Nzuve and Ng'ang'a Ng'endo (2012) assessed employee perception of performance appraisal in the Department of Immigration with specific emphasis on the Headquarters and at the Jomo Kenyatta International Airport which are the Departments two stations in the Nairobi Region. A case study was deemed appropriate as the Department of Immigration was fairly representative of the Ministries in the public 
service and thus the findings could be applied to the public service. The research methodology was descriptive with a sample of 158 employees drawn from four stratums, namely the heads of departments, immediate supervisors, officers other than heads of departments in each grade and other supervisors and staff. The study findings revealed that though performance appraisal on paper was built on solid principles, its implementation as relates to the scope of application, highlights of the old performance appraisal system, implementation of the new system, training as a direct result of performance appraisal, advantages and shortcomings of appraisal in the Department including use of the form GP 247, appraisal interviews, feedback process and quality and the relationship between appraisal and performance, motivation, reward and sanction management to a large extent falls short and thus greater sensitization was required to harness its full potential and benefits.

Shrivastava and Purang (2011) evaluated employee perception on performance appraisal in Indian banks. Perception of fairness of the performance appraisal system has been studied through nine factors. The study used independent samples t-test and qualitative analysis to study the mean differences between the two banks. Results indicated that private sector bank employees perceive greater fairness and satisfaction with their performance appraisal system as compared to public sector bank employees.

\section{METHODOLOGY}

Research Design: The study employs the crosssectional research design due to the time factor of the study which is within a single time period and the nature of the study, which seeks to determine the relationship between two variables with little to no manipulation of each variable sets (i.e. the independent and dependent variables).

Study Population: The overall study population constitute all employee of all registered Deposit Money Banks in Nigeria. While the accessible population entails all Port Harcourt Branches of registered Deposit Money banks in Nigeria. Therefore, the target population size is 645 employees across various Deposit Money Banks in Port Harcourt, Rivers state.

\section{Sampling technique}

A convenience sampling is used in exploratory research. The sampling was based on convenience but utilized a representative sample. The researcher therefore distributed 150 questionnaires in various department and 123 completed forms were received which represent $20.1 \%$ of the population which is an appropriate size for the target populations. The nonrespondents were $13.3 \%$.

Operational Definition of Variables: The basic concept of a thirty three item instrument used in this study is adopted from the study done by a student Anne Von Elverfeldt (2005) in University of Twente Netherland 3.2.1 Employees Perception on Performance. There are seven items that involve an employee's perception regarding performance appraisal. This questionnaire is based on a 5 point likert scale where 1 is the lowest and 5 is the highest rating .This scale is taken from (Lawler 81). The value of the 0.86 was the acceptable reliability of this scale (Sekaran, 2000). This instrument is modified and contains five components which are performance appraisal, procedural justice, goal setting, feedback, and pay for performance. Each component is based on five to ten items. The instrument is based on five point Likert scales 5 being the highest and 1 being the lowest Data Analysis Method: After data collection the analysis of the collected data should follow (Christensen et. al., 2001). For data analysis of the collected data a quantitative research method is used for statistical analysis. This analysis was done through SPSS 25 (Statistical Package for Social Sciences) which is inclusive of reliability and validity tests, Exploratory Factor correlation (Discriminant validity) and Regression analysis which are discussed in the following sections

- Reliability and Validity

Validity and reliability tests are used in order to get the quality of the study and testing. Reliability measures the aim and intend of the study and how the measurement tool is used is measured by Validity. (Bryman \& Bell, 2005). In this study reliability and validity both has been secured as explained in the following paragraph.

- Exploratory Factor Analysis (EFA)

Factor analysis for sampling size is assessed though Kaiser-Meyer-Olkin for the appropriateness of the data structure. Exploratory Factor analysis is used in behavioral and social sciences, marketing; product management and operation research to deal with large data is originated in psychometrics (Polit \& Beck 2012). The one standard rule of thumb in confirmatory factor analysis is, that minimum loadings should be 0.7 or higher to confirm that independent variables identified by a particular factor. However, some researchers will use lower level such as 0.4 for central factor and for other factor a value of 0.25 because 0.7 is a high standard and the real-life data may not meet this criterion.

\section{- Descriptive Statistics}

Descriptive statistic which is used to calculate central tendencies is used in this study not only to get perception about the results but to display an overview of the sample.

\section{- Correlations analysis}

In order to show association and strength in between two variables in marketing research a Correlation 
analysis is used .Karl Pearson is more frequently used correlation coefficient because it explains linear relations between $\mathrm{X}$ and $\mathrm{Y}$ variable. (Malholtra, 2010). Depending on positive or negative correlation value of the correlation will be between +1 to -1 . A +1 (strong positive correlation), indicates that the variables are positively related and -1 (strong negative correlation) indicates that the variables are related but negatively whereas 0 as an indicator of no correlation for different variable.

- Regression Analysis

In order to identify and analyze the relationship between one or more independent and dependent variables, regression analysis is used. This analysis helps the researcher to get the answer for question such as whether the relationship exists and if it exists how strong it is. The difference between regression and correlation analysis is Correlation and regression analysis are related in the sense that both deal with relationships among variables.

\section{RESULTS AND DISCUSSIONS}

\subsection{Respondents By Department}

The questionnaire which was distributed in various departments for analysis and feedback were received as per following count and percentage. The highest number of respondents wasfrom Human resource followed by IT and billing. The average length of service was 6-21 years and the education level was of the majority of the respondents were graduates and Post graduates including MBA and Engineering.

Table 1: Department Wise Participation

\begin{tabular}{ccc}
\hline Department & Count & $\mathbf{\%}$ \\
\hline HR & 17 & 13.8 \\
\hline IT & 16 & 13 \\
\hline Billing & 14 & 11.4 \\
\hline Finance & 14 & 11.3 \\
\hline Sales & 14 & 11.3 \\
\hline Operation & 8 & 6.5 \\
\hline P\&D & 7 & 5.7 \\
\hline Others & 33 & \\
\hline
\end{tabular}

\subsection{Descriptive Statistics}

To ascertain the data normality we have generated the descriptive statistic which is summarized in Table 2.

Table 2 Descriptive Analysis

\begin{tabular}{ccccc}
\hline & Mean & Std. Dev. & Skewness & Kurtosis \\
\hline Per.App & 3.498 & 0.677 & -0.786 & 0.828 \\
\hline PrJustice & 3.42 & 0.748 & -0.541 & 0.287 \\
\hline Goal. Setting & 3.745 & 0.602 & -0.336 & 0.899 \\
\hline Feedback & 3.331 & 0.814 & -0.471 & 0.115 \\
\hline Pay for.Per & 3.533 & 0.811 & -0.517 & 0.124 \\
\hline
\end{tabular}

In the above table goal setting $(\mathrm{Mean}=3.745, \mathrm{SD}=.602)$ has the lowest Skewness (0.336), and Performance Appraisal perception (Mean $=3.498, \mathrm{SD}=0.677$ ) has the highest Skewness (-0.786). The Kurtosis for all the items is positive, the highest for goal setting (Mean $=3.745, \mathrm{SD}=.602)$ is 0.899 and the lowest for feedback which is (Mean=3.331, $\mathrm{SD}=0.814$ ) and kurtosis is 0.115 . Since all the construct are positive and within the range of \pm 1.5 therefore it can be assumed that the data has normal tendency.

\subsection{Discriminate Validity}

According to Bryman the correlations analysis is a common process on one to one basis of all the items (Bryman \& Bell, 2005). In order to do regression analysis the correlation is a requirement; Bryman further highlighted that the constructs should be should be between $0.20-0.90$ for moderate level. The item needs to be dropped if its correlation is below 0 .

20. Similary if correlation value of two items is $>.90$ it also either needs to be dropped or merged (Bryman \& Bell, 2005). The results are presented in Table 3. 
Table 3 Summarized Correlation Results

\begin{tabular}{cccccc}
\hline & Per.App & Pr.Justice & Goal. Setting & Feedback & Pay for Per \\
\hline Per.App & 1 & & & & \\
\hline PrJustice & 0.448 & 1 & & & \\
\hline Goal. Setting & 0.389 & 0.528 & 1 & 1 & \\
\hline Feedback & 0.502 & 0.8 & 0.557 & 0.459 & 1 \\
\hline Pay for. Per & 0.454 & 0.478 & 0.512 & \\
\hline
\end{tabular}

Justice, goal setting, feedback and pay for performance. The relationship is highest, due to the 0.800 coefficient between feedback and procedural justice process, followed by correlation between goal setting and feedback (0.557), whereas correlation between performance appraisal fairness perception and goal setting has lowest correlation (0.389).

\subsection{Exploratory Factor Analysis (EFA)}

Exploratory factor analysis was carried out to define the underlying structure among the variables. Criteria used for retaining or dropping the items is discussed in part 3.

Table 4: EFA for the constructs

\begin{tabular}{|c|c|c|c|c|}
\hline Construct & Original & Kaiser-Meyer- & Factor & Bartlett's test of \\
\hline & Item & & Loading & \\
\hline Employees Perception & 7 & 0.882 & $85 \%$ & $\begin{array}{l}113 \\
P=000\end{array}$ \\
\hline Procedural Justice & 10 & 0.878 & $81 \%$ & $\begin{array}{l}134.8 \\
P=000\end{array}$ \\
\hline Goal Setting & 6 & 0.775 & $76 \%$ & $\begin{array}{l}0.196 .2 \\
P=.000\end{array}$ \\
\hline Performance feedback & 6 & 0.796 & $79 \%$ & $\begin{array}{l}0.273 \\
P=.0000\end{array}$ \\
\hline Pay for performance & 4 & 0.701 & $82 \%$ & $\begin{array}{l}101.1 \\
\mathrm{P}=.000\end{array}$ \\
\hline
\end{tabular}

The result shows that Kaiser-Meyer-Olkin level for All the variables are more than minimum acceptable level .06 mentioned in Hair et al., (2006). Our study results are in line with a study done in Malaysia where the KMO for Procedural Justice was .73 Cronbach alpha 0.90 , feedback 0.72 and Cronbach alpha 0.90 and for job satisfaction was 0.72 ,Alpha .84 which confirm that our data is in line with international data

Table 5: Reliability of the Constructs

\begin{tabular}{llllll}
\hline Construct & $\begin{array}{l}\text { Cronbach } \\
\text { Alpha }\end{array}$ & $\begin{array}{l}\text { Cronbach's Alpha on } \\
\text { standardized item }\end{array}$ & $\begin{array}{l}\text { No of } \\
\text { items }\end{array}$ & Mean & S.D \\
\hline Employee Perception & 0.741 & 0.741 & 7 & 3.49 & 0.685 \\
\hline Procedural justice & 0.889 & 0.892 & 10 & 3.42 & 0.75 \\
\hline Goal Setting & 0.769 & 0.781 & 6 & 3.74 & 0.6 \\
\hline Performance & 0.84 & 0.84 & 6 & 3.33 & 0.816 \\
\hline Feedback & & & & & \\
\hline Pay for performance & 0.727 & 0.729 & 4 & 3.53 & 0.8 \\
\hline
\end{tabular}

4.5. Reliability of the constructs

The instrument used for this pretest comprised of constructs which were earlier used by the researchers and therefore have established validities and reliabilities. However, the reliabilities of the used constructs were again reestablished, and the summarized results are presented below: 
The above table shows that the reliably of Procedural Justice is the highest $(\mathrm{a}=.889, \mathrm{M}=3.42, \mathrm{SD}=0.75)$. Reliabilities of the all the constructs were greater than 0.7 which are within the acceptable range indicating that the respective items have reasonable internal consistency and reliability. The Cronbach alpha for Employee perception and all independent variable is 0.913 which shows the strong correlation ship.

\subsection{Performance Appraisal and Perception (H1)}

The hypothesis of the study shows that the performance appraisal process positively influences the employee's perception of Performance appraisal was tested through Regression analysis. The summarized results are presented below:

Table 6: Summarized Regression Results

\begin{tabular}{|c|c|c|c|c|c|}
\hline \multirow[t]{2}{*}{ Variables } & \multicolumn{2}{|c|}{ Unstandardized Coefficient } & \multirow{2}{*}{$\begin{array}{c}\begin{array}{c}\text { Standard } \\
\text { Coefficient }\end{array} \\
\text { Beta }\end{array}$} & \multirow[t]{2}{*}{$\mathbf{T}$} & \multirow[t]{2}{*}{ Sig } \\
\hline & $\mathrm{B}$ & Std Error & & & \\
\hline $\begin{array}{c}\text { Performance Appraisal } \\
\text { Process }\end{array}$ & 0.874 & 0.69 & 0.753 & 12.597 & .000 \\
\hline
\end{tabular}

Dependent Variable: Perception on Performance Appraisal Note: $\mathrm{R}=0.567$; Adjusted $\mathrm{R}^{2}=.564, \mathrm{P}<.05$, $\mathrm{F}(1,122)=158.681<0$

The results of the regression indicates that the predictors performance appraisal process explains that $56.7 \%$ of the variance $\left(\mathrm{R}^{2}=0.567, \mathrm{~F}(1,122)=\right.$ $158.681, \mathrm{p}<.05)$. It was also found that performance appraisal process significantly predicts perception on performance appraisal $(\mathrm{B}=0.753, \mathrm{p}<.05)$ which according to Cohen (1998) is a large effect.

\subsection{Procedural Justice and Perception (H1A)}

The hypothesis of the study shows that procedural justice has a significant influence on employee perception on performance appraisal was tested through Regression analysis. The summarized results are presented in Table 7.

Table 7: Summarized Regression Results

\begin{tabular}{|c|c|c|c|c|c|}
\hline \multirow[t]{2}{*}{ Variables } & \multicolumn{2}{|c|}{ Unstandardized Coefficient } & \multirow{2}{*}{$\begin{array}{c}\text { Standardized coefficient } \\
\text { B }\end{array}$} & \multirow[t]{2}{*}{$\mathbf{t}$} & \multirow[t]{2}{*}{ Sig; } \\
\hline & $\mathrm{B}$ & Std.error & & & \\
\hline $\begin{array}{c}\text { Procedural } \\
\text { Justice }\end{array}$ & 0.49 & 0.069 & 0.54 & 7.06 & .000 \\
\hline
\end{tabular}

Dependent Variable: Perception on Performance Appraisal Note: $\mathrm{R}=0.292$; Adjusted $\mathrm{R}^{2}=0.282$, $\mathrm{P}<.05, \mathrm{~F}(2,122)=49.884<0$

The results of the regression indicates that the predictors performance appraisal process explains that $28.2 \%$ of the variance $\left(\mathrm{R}^{2}=0.292, \mathrm{~F}(1,22)=49.84, \mathrm{p}\right.$ $<.05)$. It was also found that performance appraisal process significantly predicts perception on performance appraisal $(\mathrm{B}=0.540, \mathrm{p}<.05)$ which according to Cohen (1998) is a large effect.

\subsection{Goal Setting and Perception.}

The hypothesis of the study shows that Goal setting has an influence on employee perception on performance appraisal was tested through Regression analysis. The summarized results are presented in Table 8 .

Table 8: Summarized Regression Results

\begin{tabular}{llllll}
\hline Variables & \multicolumn{2}{l}{ Unstandardized Coefficient } & Standard Coefficient & T & Sig \\
\hline & B & Std Error & Beta & & \\
\hline Goal Setting & 0.543 & 0.69 & 0.484 & 6.086 & .000 \\
\hline
\end{tabular}

Dependent Variable: Perception on Performance Appraisal Note: $\mathrm{R}=0.234$; Adjusted $\mathrm{R}^{2}=0.228, \mathrm{P}<$ $.05, \mathrm{~F}(1,122)=37.0344<0$

The results of the regression indicates that the predictor Goal Setting explains that $22.8 \%$ of the variance $\left(\mathrm{R}^{2}=\right.$ $0.228, \mathrm{~F}(1,122)=37.034, \mathrm{p}<.05)$. It was also found that performance appraisal process significantly predicts perception on performance appraisal $(\mathrm{B}=$
0.484, $\mathrm{p}<.05)$ which according to Cohen (1998) is a large effect.

4.9. Feedback and Perception (H1c)

The Hypothesis Feedback has an influence on employee perception on performance appraisal was tested through Regression analysis. The summarized results are presented in Table 9. 
Table 9: Summarized Regression Results

\begin{tabular}{llllll}
\hline Variables & \multicolumn{2}{l}{ Unstandardized Coefficient } & Standard Coefficient & T & Sig \\
\hline & $\mathrm{B}$ & Std & Beta & & \\
\hline Feedback & 0.465 & 0.63 & 0.558 & 7.395 & .000 \\
\hline
\end{tabular}

Dependent Variable: Perception on Performance Appraisal Note: $\mathrm{R}=0.311$; Adjusted $\mathrm{R}^{2}=0.306, \mathrm{P}<$ $.05, \mathrm{~F}(1,122)=54.687<0$

The results of the regression indicates that the predictor Feedback explains $30.6 \%$ of the variance $\left(\mathrm{R}^{2}=0.306, \mathrm{~F}\right.$ $(1,122)=54.687, p<.05)$. It was also found that Feedback significantly predicts perception on performance appraisal $(\mathrm{B}=0.558, \mathrm{p}<.05)$ which according to Cohen (1998) is a large effect.

4.10. Hypothesis Pay for Performance; (H1D)

The Hypothesis pay for performance has an influence on employee perception on performance appraisal was tested through Regression analysis. The summarized results are presented in Table 10.

Table 10: Summarized Regression Results

\begin{tabular}{|c|c|c|c|c|c|}
\hline Variables & Unstandardized Coefficient & & Standard Coefficient & $\mathbf{T}$ & Sig \\
\hline & B & Std & Beta & & \\
\hline Pay for & 0.384 & 0.66 & 0.458 & 5.672 & .000 \\
\hline
\end{tabular}

Dependent Variable: Perception on Performance Appraisal Note: $\mathrm{R}=0.210$; Adjusted $\mathrm{R}^{2}=0.203$, $\mathrm{P}<.05, \mathrm{~F}(1,122)=32.164<0$

The results of the regression indicates that the predictor Feedback explains $20.3 \%$ of the variance $\left(\mathrm{R}^{2}=0.203, \mathrm{~F}\right.$ $(1,122)=32.164, p<.05)$. It was also found that Feedback significantly predicts perception on performance appraisal $(\mathrm{B}=0.458, \mathrm{p}<.05)$ which according to Cohen(1998) is a large effect.

\section{DISCUSSION AND CONCLUSION}

This study which primarily involved a survey conducted in the financial industry (i.e Deposit Money banks) seeks to analyze the employee perception of the implementation of Performance appraisal system. Although the company had implemented the new performance appraisal system about a decade ago this study was the first ever attempt made to evaluate the perception of employees regarding the system. The Sui southern Gas Company is a Semi-government organization as was the case with other Government organizations had the archaic Annual Confidential Report in place until 2000.

The overall result of the study shows that the respondents on an overall basis had a positive perception on performance appraisal process. In this study one hypothesis and four sub-hypothesis were developed and tested. All the hypotheses were substantiated and were consistent to earlier studies. The results of the hypothesis and its relevance to earlier studies are discussed in the following sections

\subsection{Hypothesis 1}

The Hypothesis on the relationship of performance appraisal procedure as a whole has no effect on employees performance appraisal was substantiated
(Table 7). These answers the Research Question 1, which is: What is the effect of performance appraisal procedure (as a whole) on employees' perception about Performance appraisal?

Judge \& Ferris (1993) observed that appraisal procedure as a whole is significant on employee perception towards perception of performance appraisal. Bowen \& Ostroff (2004) also emphasized that the fairness of appraisal performance also positively effects employee's perception of performance appraisal system. Others in their studies have also found that the fairness in the appraisal system as a whole would lead to positive effect on employee perception towards appraisal system (Cropanzano, 2001).

\subsubsection{Hypothesis 1A}

The Hypothesis on the relationship of procedural justice and employee perception on performance appraisal was substantiated ( Table 7). This answers the Research Question 2, which is: What is the effect of Procedural justice on employees' perception of Performance appraisal?

This result related to the relationship between Procedural Justice and Employee Perception on performance appraisal is consistent to some studies and while in consistence to other studies. Judge \& Ferris (1993) observed that reward and promotion besides other HRM factors are important factors during performance appraisal to influence employee perception. Bowen \& Ostroff (2004) discussed that HRM decision makers agreed on two factors which are important for developing employee perception. These factors are the system fairness and procedural justice. Cropanzano (2001) also observed that procedural 
justice in organization put a positive impact on employee perception (Cropanzano,2001) .

5.1.2. Hypothesis 1B

The Hypothesis on the relationship of goal setting and employee perception on performance appraisal was substantiated (Table 8). These answers the Research Question 3, which is: What is the effect of goal setting on employees' perception of Performance appraisal?

This result related to the feedback and employee perception on performance appraisal is consistent to some studies and in consistence to other studies. Employee perception is goal setting. The literature review shows that goal setting and its proper evaluation has influenced employee perception .three different studies has observed and suggest that goal setting and feedback are interrelated. In order to change the employee behavior and performance in a positive way goal setting and feedback combination is the appropriate combination (Locke \&Bryan (1969), Erez (1977) and (Latham et al., (1978).Various studies have confirmed practical utility of goal setting as a method changing of behavior and performance (Latham \& blades ,(1975) Latham \& kinne,(1974). A study on utilizing feedback and goal setting has demonstrated that feedback and goal setting can be used to improve the performance appraisal skills (Waheed et al., 2018). During Literature search Majority of the goal setting discussion is in setting not related to appraisal however the above studies are related to the appraisal evaluation and the Longenecker has mentioned in his study also the relationship of goal setting in relationship with the appraisal and further emphasized that if the goal setting is effective that leads to greater employee satisfaction.

\subsubsection{Hypothesis $1 \mathrm{C}$}

The Hypothesis on the relationship of feedback and employee perception on performance appraisal was substantiated (Table 9). These answers the Research Question 4, which is: What is the effect of feedback on employees' perception of Performance appraisal?

This result related to the feedback and employee perception on performance appraisal is consistent to some studies and in consistence to other studies. Feedback on performance is another important area where the employee perception can be influenced with regular and timely feedback on his performance .This topic is widely discussed in detail in various studies Erdogan (2002) mentioned feedback is a major factor which effect employee perception. He further mentioned about the procedure while giving feedback. Erdogan viewed feedback as integral part of the PA process and is also an important component of PA process. Employee perception about performance appraisal system will be positive if they know that the appraisal process is useful tool to get feedback which enables them to improve their performance (Mullins, 2007). Cleveland and Murphy (1989) in their research article based on 243 responded interview has confirmed that performance appraisal has greatest impact on salary administration and performance feedback.

5.1.4. Hypothesis 1D

The Hypothesis on the relationship of pay for performance and employee perception on performance appraisal was substantiated (Table 10). These answers the Research Question 5, which is: What is the effect of pay for performance on employees' perception of Performance appraisal?

This result related to the feedback and employee perception on performance appraisal is consistent to some studies and in consistence to other studies. Performance base pay is another important and emotional factor for most of the employees. However performance base pay is only part of the reward system which also includes non-financial rewards. Many researchers have mentioned that the discussion on pay during the performance appraisal review discussion session has shown higher employee satisfaction Stephhan \& Loveland, (1986). De Silva (1998) has also mentioned that performance related pay system has little impact on employee overall behavior if used in isolation. For a Performance appraisal system to be effective in relations to pay for performance, the salary adjustment should follow after the performance review process is conducted, Boice \& Kleiner (1997).

5.1.1. Implication for Managers and Policy Makers Majority of the respondents are very positive about the contents of the forms used by the company for documenting Performance appraisal. The forms and the guidelines are very well explained. The respondents agree that Performance appraisal system has encouraged the employees to communicate openly with their supervisor. Majority of the respondents agree with the contents of the instrument. However at the same time the respondents did not agree with question that "Performance appraisal measure accurately what I do on my job". The reason being the form used for performance appraisal is the same for whole organization, the respondents observed that the form does not measure what I do on my job implying that the organization need to tailor the performance appraisal form in line with job specification of the person being rated.

\section{REFERENCES}

1. Aarathy, T. S., \& Raju, D. D. V. (2018). Employee Perception towards Performance Appraisal System in it Sector. International Journal of Mechanical Engineering and Technology, 9(5), 131-135.

2. Alan Bryman and Emma Bell (2007) Business Research Methods (2nd Edition), Oxford University Press.

3. Alexandre, G. (1991). Pay for Performance: Evaluating performance appraisal and merit pay". In E. w. George T. Milkovich and Alexandra K. 
Wigdor, Pay for performance (p. 221). ISBN: 30957212-6, 224 pages, $6 \times 9$, (1991).

4. Anderson, J. R (2002). Measuring Human Capital Performance appraisal effectiveness. and economics. Midwest Academy of Management Conference, 2002

5. Armstrong, M. (2006). "performance management key strategies and practical guidelines "(3. Edition, ed.) London N1 9JN Philadelphia PA19147, United Kingdom USA: www.kogan-page.co.uk.

6. Aycan et,al . (2000). Impact of Culture on Human Resource Management Practices" A 10- Country Comparison, Applied Psychology: An International Review, 49(1), 192-221

7. Aycan, Z., Kanungo, R. N., Mendonca, M., Yu, K., Deller, J., Stahl, G. and Kurshid,

8. Banks, C. G. and Murphy, K.R. (1985). Toward Narrowing the Research Practice Gap in Performance Appraisal. Personnel Psychology, 39, 335-345.

9. Barrier, M. (1998). Reviewing the Annual Review. Nation's Business, 86,9, 32.

10. Bernthal, P.R., Sumlin, R., Davis, P., \& Rogers, R. (1997). "Performance management practices survey report. "Pittsburgh, PA: Development Dimensions International.

11. Boachie-Mensah, F. O., \& Seidu, P. A. (2012). Employees' perception of performance appraisal system: A case study. International journal of business and management, 7(2), 73.

12. Boice, D.F. and Kleiner, B.H. (1997). Designing effective performance appraisal systems, Work Study, 46, 6, 197-201.

13. Boyce, L. A., Wisecarver, M. M., \& Zaccaro, S. J. (2005). Understanding, predicting, and supporting leader self-development. (Technical Report, No. 1173). Arlington, VA: U.S.Army Research Institute for the Behavioral and Social Sciences.

14. Bretz, R., and Milkovich, G. (1989) Performance Appraisal in Large Organizations: Practice and Research Implications." Working paper \#89-17. Center for Advanced Human Resource Studies, Cornell University, Ithaca, N.Y.

15. Bricker, G. A. (1992). Performance Agreements: The Key to Increasing Motivation, Sales and Marketing, 144, 69-70.

16. Brown, D. G. 1987. Development of performance standards: A practical guide. Public Personnel Management, 16: 93-114.

17. Bruin, J. 2006. new test: "command to compute new test". UCLA: Academic Technology Services, Statistical Consulting Group.http://www.ats.ucla.edu/stat/stata/ado/analy sis/.

18. Bryman, A. \& Bell, E. (2005), Business research methods, Liber, Malmo

19. Cameron, K. (1980). Critical questions in assessing the organisation effectiveness. Organisational Dynamics, 66-80.

20. Canet-Giner, T., Redondo-Cano, A., Saorín-Iborra, C., \& Escribá-Carda, N. (2019). Impact of the perception of performance appraisal practices on individual innovative behavior. European Journal of Management and Business Economics.

21. Cascio, W. F. and Bernadin, H.J. (1981).Implication of Performance Appraisal Litigation for Personnel Decisions. Personnel Psychology.34, 2, 211-226.

22. Christensen, L., Engdahl, N., Graas, C., Haglund, L. (2010). "Market research a hand book". Third Edition. Student litteratur AB, Lund, Sweden.

23. Cleveland J. N., \& Murphy, K.R. 1992. Analyzing performance appraisal as goal-directed behavior. Research in Personnel and Human Resources Management, 10, 121-185.

24. Cleveland JN, Murphy KR, Williams RE. (1989). multiple uses of performance appraisal: Prevalence and correlate. Journal of Applied Psychology, 74, 130-135.

25. Clinton O. Longenecker, S. J. Goff (1992). Performance Appraisal Effectiveness: A mtter of Perspective. SAM Advanced Management Journal.

26. Conway, Huffcutt A Review and Evaluation of Exploratory Factor Analysis Practices inOrganizational Research Organizational Research Methods, Vol. 6 No. 2, April 2003 147168 Sage Publications

27. Curzi, Y., Fabbri, T., Scapolan, A. C., \& Boscolo, S. (2019). Performance Appraisal and Innovative Behavior in the Digital Era. Frontiers in psychology, 10, 1659.

28. Dalton, M. (1996). Multirater Feedback and Conditions for Change. Consulting Psychology Journal, 48 (1), 12-16

29. David Thomson, A. S. (1999). The case of management performance appraisal in a hong kong public sector hospital. Asian Journal of Public administration, 21 (1), 114-144.

30. Davis,J.A.(1971) Elementary Survey Analysis.Englewood Cliffs, NJ: Prentice -Hall

31. Deborah F. Boice, B. H. Kleiner (1997). Designining effective performance appraisal system. International Journal of Productivity and Performance Management, 197-201.

32. DelPo, A. (March 2007). The performance Appraisal Handbook. In The Performance appraisal Handbook 2nd edition (p. 224). isBn-13: 978-1-4133-0567-8.

33. Dessler, G. 2000. Human Resource Management. $8^{\text {th }}$ edition. New Jersey: Prentice Hall International, Inc. De Silva, S.(1998).Performance related and skills -based pay: an introduction international Labour Office. Geneva

34. Dobbins, G.H., Cardy, R.L. and Platz-vieno, S.J. (1990). A Contingency Approach to Appraisal Satisfaction: An Initial Investigation of the Joint Effects of Organizational variables and Appraisal Characteristics, " Journal of Management, 16, 619632.

35. Dolan, L. Shimon, Denis, Moran (1995), The effect of rater-rate relationship on rate Perception of the appraisal process" International journal of management volume. 12 No.3 September 1995 p 337-351 
36. Dorfman, P. W., Stephan, W. G., \& Loveland, J. 1986. Performance appraisal behaviors: Supervisor perceptions and subordinate reactions. Personnel Psychology, 39: 579-597.

37. Edmonstone, J. 1996. Appraising the state of performance appraisal, Health Manpower Management 22 (6): 9-13..

38. Elverfeldt, A. v. (20.6.2005). Performance appraisal - how to improve its effectiveness. research work, University of Twente, Enchede., 20.6.2005)

39. Erdogan, B. (2002, may). Antecedents and consequences of justice perceptions. Human Resource Management Review, 12 (2002) 555-578.

40. Erez, M. Feedback: A necessary condition for the goal setting-performance relationship. Journal of Applied Psychology, 1977, 62, 624-627.

41. Field, A. (2000). Discovering Statistics using SPSS for Windows. Sage: London.

42. Fisher, C. (2004) Researching and Writing a Dissertation for Business Students. Harlow, Pearson Education Ltd.

43. Furnham A, 'Starved of Feedback', the Independent, 5 December 1996.

44. Gay, L.R. and Airasian, P. (2003) Educational Research. New Jersey: Upper Saddle River.Griffln ,W.G (1987) Management .second edition .Houghton Miffin,. Boston

45. Gomez-Meji, L. R. (1990). Increasing Productivity: Performance Appraisal and Reward Systems. Personnel Review,19 (2), 21-46.

46. Grote, Dick, and Grote, Richard C. (1996). The Complete Guide to Performance Appraisal. New York:AMACOM Div., American Management Association.

47. Hafiz Muhammad Ishaq, M. Z. (2009). Effectiveness of Performance Appraisal: Its Outcomes and. European Journal of Social Sciences.

48. Hair,J.F.,Anderson,R.E,. Tatham,R.L., \& Black, W.C(2006). Multivariate data analysis. New jersey: Prentice Hall International Inc

49. Harris, C. (1988). A Comparison of Employee Attitude Toward Two Performance Appraisal Systems. Public Personnel Management, 17 (4), 443-456

50. Heinrich, Carolyn. 2002. Outcome-based performance management in the public sector: Implications for government accountability and effectiveness. Public Administration Review 62 (6): 712-25.

51. Hewitt Associates.(1994). The Impact of Performance Management on Organizational Success. Hewitt Associates LLC Henderson, R. (1984). Practical Guide to Performance Appraisal. Reston Publishing, Virginia.

52. Ismail.A,Sulaiman.A.Z,Mohamed A.H \& Sani.M.R (2011) Procedural Justice as a Moderator in the relationship between performance appraisal communication and job satisfaction WWW.revistanegotium.org.ve 19(7) 162-186
53. Joseph F.hair,jr,William C.black,Barry J.Babin,Rolph E.Anderson. Multivariate data analysis ,7/e. 2010 Pearson Prentice Hall

54. Kaplan S.R \& David P.Norton" Using the balance Scorecard as a Strategic ManagementSystem"Harvard Business review January-February 1996

55. Kim, J. S., \& Hamner, W. C. Effect of performance feedback and goal setting on productivity and satisfaction in an organizational setting. Journal of Applied Psychology, 1976, 61, 48-57.

56. Lansbury, $R$. (1988). performance management A process approach. Asia Pacific journal of Human Resource,46-65..

57. Larry M. Dooley Advances in Developing Human Resources Vol. 4, No. 3 Chapter 6. August 2002 335-354 Sage Publications

58. Latham, G. P., \& Yukl, G. A. A review of research on the application of goal setting in organiza-tions. Academy of Management Journal, 1975a, 18, 824845.

59. Likert, Rensis (1932): A technique for the measurement of attitudes, Archives of Psychology, 140(1), 44-53 (the original article).

60. Litwin, M (1995) How to measure survey reliability and validity Thousand Oaks CA .Stage

61. Locke, E., Shaw, K., Saari, L., and Latham, G. 1981 Goal setting and task performance, 1969-1980. Psychological Bulletin 40:125-152.

62. Longenecker, C.O. 1997.Why managerial performance appraisals areineffective: causes and lessons. Career Development International 2 (5):212-218

63. Lyster, Stephanie, and Anne Arthur, 199 PreWritten Employee Performance Appraisals: The Complete Guide to Successful Employee Evaluations and Documentation. Atlantic Publishing Company, 2007.

64. Malholtra, N. (2010), "Marketing research: an applied orientation" Sixth edition, Pearson education, New Jersey

65. Mani, B.G. (2002). Performance Appraisal Systems, Productivity, and Motivation: A Case Study, " Public Personnel Management, 31(2), 141 159.

66. Marshall, MN. Sampling for qualitative research. Family Practice 1996; 13: 522-525.

67. Martin, D. C. (1998). Performance Appraisal: Maintaining System Effectiveness. Public Personnel Management.

68. Miller, R., Acton, C., Fullerton, D., Maltby, J. (2002), "SPSS for Social Scientists", first edition, Palgrave McMillan, New York

69. Mohrman, A.M. Jr. and Resnick-West, S.M. and Lawler III., E.E. 1989. Designing Performance Appraisal Systems - Aligning Appraisals and Organizational Realities. San Francisco: JosseyBass Publishers.

70. Moravec, M. (1996). BRINGING PERFORMANCE MANAGEMENT OUT OF THE STONE AGE. Management Review, 85 (2), 38-42. 
71. Morris, T. \& Wood, S. (1991) Testing the survey method; continuity and change in British industrial relations. Work, Employment and Society. Vol 5, No. 2, pp259-282.

72. Mullins, J.L.(2007). Management and organizational behavior (8th edn.).Edinburgh Gate, UK: Prentice Hall; Financial Times.

73. Murphy K.R , \& Cleveland J. N.1995. Understanding performance appraisal: social, organization, and goal-based perspectives. Thousand Oaks, CA: Sage.

74. Nathan, B. R., Mohrman, A. H., Jr., \& Milliman, J. (1991). Interpersonal relations as a context for the effects of appraisal interviews on performance and satisfaction: A longitudinal study. Academy of Management Journal, 34, 352-369.

75. Newsroom, J.W. \& Davis, K. 1993. Organizational behavior: human behavior at work. Ed. ke-9. New York: McGraw-Hill.

76. Nick, N. (June 1996, June Saturday). public sector performance appraisal : a case study. public personnel management.

77. Nzuve, S., \& Ng'ang'a Ng'endo, M. (2012). An assessment of employees' perception of performance appraisal: A case study of the Department of Immigration-Nairobi. Available at SSRN 2192862.

78. Oreille, M., Wathey, D., \& Gelber, M. 2000, „ISO 14031: Effective mechanism to environmental performance evaluation. Corporate Environmental Strategy", 1(3), 267-275.

79. P.Norton, R. S. (1996). Using the balance scorecard as a strategic management system. Harward business Review,75-85.).

80. Peter Allan and Stephen Rosenberg, "Getting a Performance Appraisal System under Way: New York City's Experience," Public Administration Review, (1981), Vol. 40, No. 4, pp. 372-379

81. Polit DF Beck CT (2012). Nursing Research: Generating and Assessing Evidence for Nursing Practice, 9th ed. Philadelphia, USA: Wolters Klower Health, Lippincott Williams \& Wilkins.

82. Prince, J. B., \& Lawler, E. E. (1986). Does salary discussion hurt the developmental Performance appraisal? Organizational Behavior and Human Resource Decision Processes, 37, 357-375

83. Rasad, R. I. (2005, July ). Employee performance Evaluation By AHP : a casestudy. DISAHP ,Honolulu july 8-10, 2005.

84. Robert.K.Yin. (2009). Case study research, Design \& methods (4th ed.). sage publications.

85. Roberts, G.E. (2003). Employee Performance Appraisal System Participation: a Technique that Works. Public Personnel Management, 30 (1), 8998

86. Roberts, I. (2001). Reward and performance management. In I. Beardwell \& L. Holden (Eds.), rd Human resource management: A contemporary approach (3 edn., pp. 506-558). Edinburgh: Pearson.

87. Robins, S.P. and Couter, M. 1999. Management. $6^{\text {th }}$ edition. New Jersey: Prentice-Hall
88. Rogelberg G.S and Alexandra Luong 1998) Nonresponse to Mailed Surveys: A Review and Guide Department of Psychology, Bowling Green State University, Volume 7 number 2.

89. Rogers, R., Miller, L., \& Worklan, J. (1993). Performance Management: What's Hot-What's Not. Development Dimensions International and the Society for Human Resources Management

90. Sahl, R.J. (1990), "Design effective performance appraisals", Personnel Journal, October, pp.

91. Salant.P., \& Dillman .D. (1994) .how to conduct your own survey.New York Wiley

92. Sashkin, M. (1981). Appraising Appraisal Ten lessons from Research for Practice. Organizational Dynamics,9 (3), 37-50.

93. Schmidt, A. M., \& Ford, J. K. (2003). Learning within a learner control training environment: The interactive effects of goal orientation and metacognitive instruction on learning outcomes. Personnel Psychology, 56, 405-429.

94. Sekaran, U. (2003). Research methods for business: A skill building approach. New York: John Wiley \& Sons, Inc.

95. Shrivastava, A., \& Purang, P. (2011). Employee perceptions of performance appraisals: a comparative study on Indian banks. The International Journal of Human Resource Management, 22(03), 632-647.

96. Sicilia-Aguilar, A., et al., 2006, ApJ, 638, 897

97. Stephanie Lyster, Antigone Eteoklis Arthur, Anne Arthur"199 Pre-Written Employee Performance Appraisals: The Complete Guide to Successful Employee Evaluations and Documentation"

98. Stevens, M. (1990). Evaluating Employees from the Outside in," Small Business Reports, 15(8), 14-16.

99. Tyler,T.R.,Rasinski,K., \& McGraw ,K (1985) .The influence of perceived injustice on the endorsement of political leaders .Journal of applied Social Psychology, 15:700-725

100. Verespej, M.A. (1990). Performance Reviews Get Mixed Reviews. Industry Week. 239, 49-54.

101. Waheed, A., Abbas, Q., \& Malik, O. F. (2018). Perceptions of performance appraisal quality'and employee innovative behavior: do psychological empowerment and 'perceptions of HRM system strength 'matter?. Behavioral Sciences, 8(12), 114. 